STUDIA EDUKACYJNE NR 51/2018

EWA SOLARCZYK-AMBROZIK

Uniwersytet im. Adama Mickiewicza

$w$ Poznaniu

\title{
CAŁOŻYCIOWE UCZENIE SIĘ JAKO IDEA EDUKACYJNA, POLITYKA, STRATEGIE DZIAŁAŃ I ZMIENIAJĄCY SIĘ KRAJOBRAZ EDUKACYJNY RZECZYWISTOŚCI
}

\begin{abstract}
AвSTRACт. Solarczyk-Ambrozik Ewa, Całożyciowe uczenie się jako idea edukacyjna, polityka, strategie działań i zmieniajacy się krajobraz edukacyjny rzeczywistości [Life-long Learning as an Educational Idea, Policy, Action Strategy and an Ever-changing Landscape of Learning Reality]. Studia Edukacyjne nr 51, 2018, Poznań 2018, pp. 23-37. Adam Mickiewicz University Press. ISSN 1233-6688. DOI: 10.14746/ se.2018.51.2
\end{abstract}

The idea of lifelong learning has appeared in 1920's, situating on the background of the phenomena of adult education, which, since it emergence, have been a long way - as shall be defined - from the socialization of the masses to the empowerment of individuals, and the prospect of such changes is included into a peculiar continuum - between industrialization and urbanization, and the knowledge society.

Nowadays the problem of lifelong learning goes far beyond the traditionally perceived adult education. Inscribing itself into the global educational discourse becomes its essential issue - it refers to the questions of educational possibilities and opportunities in the different socio-cultural contexts. It dominates the discussions on adult education, vocational training and higher education, providing a theoretical framework for the development of relevant policy and action strategies, but in addition it plays a crucial role in economic debates on labour market, quality, capacity, sustainable development, learning in organizations and - importantly - it also appears in non-education-related debates including such issues as: social exclusion, unemployment, environmental protection, active citizenship and health. The phenomenon of lifelong learning allows to respond to such conceptual categories as flexibility and uncertainty. As a result of technological advances, competition creates the need for flexibility which in case of learners is, in the one hand, recognised as emancipation, and in the other, as a threat to individuals enable to meet the new requirements associated with individual responsibility for the course of the educational path. Alongside opinions presenting anti-institutional interpretation of lifelong learning, the "supply" of an institutional offer of adult education is raised. The conclusions of the presented analyses results in showing lifelong learning as a phenomenon, which is not unambiguously evaluated, since it may by understood as a the purpose, a process, an effect, a form of self-realization, a socio-cultural constraint, and at least as an important field of educational reality in the word of new challenges.

Key words: lifelong learning, adult education, educational policy, opportunities and barriers, technological advancement and cultural changes, individual responsibility for the course of the educational path (individualization of the educational path) 
Idea edukacji ustawicznej pojawiła się już w latach 20. XX wieku, sytuując się na tle fenomenu edukacji dorosłych, która także od czasu swego zaistnienia „przeszła” długą drogę - można ją określić - od „uspołecznienia” mas do upodmiotowienia jednostek, zaś perspektywa tych zmian zawiera się w swoistym kontinuum - pomiędzy uprzemysłowieniem i urbanizacją a społeczeństwem opartym na wiedzy i zrównoważonym rozwojem ${ }^{1}$. Współcześnie jednak problematyka całożyciowego uczenia się wykracza znacznie poza tradycyjnie rozumianą edukację dorosłych. Wpisując się w globalny dyskurs edukacyjny, staje się jego zasadniczą kwestią - dotyka problemów związanych z możliwościami oraz szansami edukacyjnymi w różnych kontekstach kulturowych. Współcześnie także dominuje w dyskusjach dotyczących edukacji dorosłych, kształcenia zawodowego, szkolnictwa wyższego, zapewniając ramy teoretyczne dla budowania odnośnej polityki, jak i strategii działań, jednak obok tego odgrywa kluczową rolę w debatach ekonomicznych dotyczących rynku pracy, jakości, wydajności, zrównoważonego rozwoju, uczenia się w organizacjach i - co ważne dla rozumienia istoty przeobrażeń pojawia się w debatach nie związanych bezpośrednio z edukacją, takich jak: wykluczenie społeczne, bezrobocie, ochrona środowiska, aktywne obywatelstwo, zdrowie publiczne ${ }^{2}$. Pojęcie to związane jest z teorią kapitału ludzkiego, która szczególnie podkreśla wartość inwestowania w edukację i kształcenie, ponieważ ma to z założenia przynosić zyski w postaci rozwoju gospodarczego oraz rozwoju jednostek i społeczeństwa ${ }^{3}$.

Można powiedzieć, że obecne sformułowania całożyciowego uczenia się oraz społeczeństwa uczącego się mają swój początek w ekonomicznych przemianach zachodzących w latach 80 . w demokracjach zachodnich, a także w nowych kierunkach, które obierała polityka społeczna i gospodarcza w latach 90. XX wieku. W latach 80. miała miejsce koncentracja uwagi na ekonomii, częściowo jako następstwo neoliberalizmu zapoczątkowanego w polityce zachodniej, a częściowo w wyniku przekształceń gospodarczych. Większość dyskusji politycznych lat 90. dotyczyła transformacji gospodarczej, głównie jednak w kontekście przemian technologicznych, przemian w komunikacji i produkcji powodujących zwiększenie międzynarodowej konkurencji. Wraz z kurczeniem się odległości w wyniku postępu technologicznego i pojawie-

${ }^{1}$ E. Solarczyk-Ambrozik, Makrostrukturalne uwarunkowania zmienności systemu oświaty dorostych, [w:] Zmiana społeczna a kompetencje edukacyjne dorostych, red. K. Przyszczypkowski, E. Solarczyk-Ambrozik, Koszalin 1995; taże, Ksztatcenie ustawiczne w perspektywie globalnej i lokalnej. Między wymogami rynku a indywidualnymi strategiami edukacyjnymi, Poznań 2009.

2 E. Solarczyk-Ambrozik, Uczenie się przez całe życie jako rzeczywistość edukacyjna. Dyskurs całożyciowego uczenia się w tle zmian społeczno-ekonomicznych, [w:] Całożyciowe uczenie się jako wyzwanie dla teorii i praktyki edukacyjnej, red. E. Solarczyk-Ambrozik, Poznań 2013.

3 B. Morgan-Klein, M. Osborne, The Concepts and Practices of Lifelon Learning, London - New York 2007. 
niem się konkurencji wyzwaniem stała się globalizacja. Zmiany te spowodowały równocześnie zwiększenie tempa codziennego życia i większą niepewność w świecie, w którym rządy narodowe sprawują coraz mniejszą kontrolę nad międzynarodowymi korporacjami ${ }^{4}$.

Rozumieniu całożyciowego uczenia się jako zjawiska społeczno-kulturowego sprzyja odniesienie się do innych aspektów życia społecznego, takich jak między innymi kultura posttradycyjna, charakteryzująca się większym pluralizmem i zwiększoną niepewnością we wszystkich aspektach życia (na przykład we wzorach funkcjonowania rodziny), większą różnorodnością oraz heterogenicznością wartości ${ }^{5}$. Fenomen całożyciowego uczenia pozwala przybliżyć odniesienie do takich kategorii pojęciowych, jak elastyczność i niepewność. Zwiększona w efekcie postępu technologicznego konkurencja międzynarodowa stwarza potrzebę elastyczności, która w przypadku uczących się ujmowana jest jako emancypacyjna, ponieważ otwiera możliwości nowych rodzajów praktyki. Oznacza to jednak równocześnie, że jednostki w elastyczny sposób, na własną odpowiedzialność, łączą uczenie się z pracą, zwiększając w ten sposób tempo życia, jak również intensyfikując równoczesne obciążenie pracą i nauką. Pojęcia szybkiego reagowania i elastyczności wdrażane są w sposób, który promuje zmianę instytucjonalną, jaką jest na przykład urynkowienie edukacji i kształcenia. Innymi kategoriami pojęciowymi, istotnymi dla rozumienia fenomenu uczenia się przez całe życie, obok indywidualnej odpowiedzialności za przebieg ścieżki edukacyjnej, są kategorie „dostępu” do różnych form kształcenia oraz „orientacja na uczącego się" (learner centredness), które wiążą się z humanistycznym podejściem do procesu uczenia się oraz z dyskursem sprawiedliwości społecznej, a mimo tego jednak mogą być wdrażane w sposób pozwalający jednostkom na kierowanie sobą będące w zgodzie z przyjętymi i odzwierciedlonymi w polityce strategiami uczenia się przez całe życie ${ }^{6}$.

Jak wskazują B. Morgan-Klein i M. Osborne, opisując fenomen całożyciowego uczenia się, warto wyjaśnić zakres używanych powszechnie pojęć, które odnoszą się do ścieżek edukacyjnych uczących się oraz ich narracji. Termin „kariera kształcenia się”, który spopularyzowali między innymi Bloomer i Hodkinson, odnosi się do wydarzeń, czynności i interpretacji rozwijających w czasie indywidualne skłonności do uczenia się. Trajektorie uczenia się to ścieżki pokonywane przez jednostki na przestrzeni ich życia, a ponieważ niektóre jednostki lub grupy jednostek znajdują się w lepszej pozycji społecznej, powoduje to, że ich trajektorie różnią się. Samoukierunkowanie, postrzegane czasem jako predyspozycja do przejmowania odpowiedzialności za wyzna-

\footnotetext{
${ }^{4}$ Tamże, s. 2.

${ }^{5}$ R. Usher, R. Edwards, Lifelong Learning - Sings, Discourses, Practices, Dordrecht 2007.

${ }_{6}^{6}$ B. Morgan-Klein, M. Osborn, The Concepts and Practices.
} 
czanie własnej kariery i trajektorii uczenia się, równoważone jest przez okoliczności personalne ${ }^{7}$.

Orientacja na uczącego się, obok przesunięcia nacisku z kształcenia na uczenie się, będąca wyrazem przesunięcia paradygmatycznego w edukacji dorosłych, nie jest jednak zawsze wyrazem humanistycznego, andragogicznego podejścia do procesu uczenia się, ponieważ cele uczestniczenia w nim są coraz częściej narzucane z zewnątrz, zgodnie z agendami całożyciowego uczenia się, wyrażonymi w polityce edukacyjnej formułowanej na różnym poziomie $^{8}$. W związku z tym podkreśla się znaczenie orientacji na wyniki, szczególnie zaś w kontekście dążności do konstruowania nowych jednostkowych tożsamości, lepiej przystosowanych do realizowania osiągnięć i społecznych oczekiwań. Tożsamości te są dla jednostek atrakcyjne, ponieważ przedstawiane są jako sposób radzenia sobie z niepewnościami współczesnego życia, a w związku z tym jako mające charakter wzmacniający (empowering). Są dyskursywnie osadzone w badaniach, polityce i praktyce, kładących nacisk na odpowiedzialność jednostki za kształt własnego życia, jej większą elastyczność, przedsiębiorczość, kreatywność i autonomię. Nacisk na wyniki obejmuje również nieformalne formy uczenia się, między innymi działania mające na celu optymalizację własnego ja, przedstawione jako rodzaj utylitarnej przyjemności (jak na przykład dbanie o ciało, stosowanie diet, gimnastyka) ${ }^{9}$.

W dyskursach całożyciowego uczenia się optymalizacja własnego ja jest zatem czynnością przedsiębiorczą; jednostka dokonuje odpowiedzialnych wyborów, które są przystosowane do nowych praktyk pracy i są także wyrazem odpowiedzialności za przebieg własnego życia, jako opozycyjnej postawy w stosunku do oczekiwań wobec państwa w zakresie wsparcia edukacyjnego. Jak argumentuje Crowther, nacisk na podmiotowość i tożsamość w całożyciowym uczeniu się pełni funkcję regulacyjną - koncepcja całożyciowego uczenia się przenosi odpowiedzialność za uczenie się na jednostki, umniejszając rolę państwa opiekuńczego, kryjąc redukcję publicznej sfery demokratycznej, a także traktując ludzi jako podmioty polityki, co w założeniach ma zapewnić im sprawne poruszanie się we wspaniałym świecie elastycznego kapitalizmu ${ }^{10}$.

Badacze podejmujący problem indywidualnej odpowiedzialności za przebieg ścieżki edukacyjnej często rozpatrują go też, co zostało już wyżej za-

7 Tamże, s. 21.

${ }^{8}$ R. Usher, R. Edwards, Lifelong Learning - Signs.

9 B. Skegss, Class, Self, Culture, London 2004, za: B. Morgan-Klein, M. Osborn, The Concepts and Practices, s. 18.

${ }^{10} \mathrm{~J}$. Crowther, "In and Against" lifelong learning: Flexibility and corrosion of character, International Journal of Lifelong Education, 2004, 23(2), s. 125-136. 
sygnalizowane, w kontekście społecznie konstruowanej tożsamości uczących się. Procesy te opisane są $\mathrm{w}$ teoriach edukacyjnych, które proponują różne modele uczącego się, a także, co najważniejsze, mają swoje odzwierciedlenie $\mathrm{w}$ dyskursach całożyciowego uczenia się. Dyskursy te oferują indywidualizm normatywny, z naciskiem na praktyki samozarządzania oraz samooptymalizację. Jednostkom zaleca się uczestniczenie w procesie całożyciowego uczenia się, rozumianego jako sposób adaptacji do społecznych i ekonomicznych przemian. Dlatego, dyskursy na temat całożyciowego uczenia się „zapraszają" jednostki do identyfikowania się z nowymi narracjami. Te społeczne narracje dotyczące "samooptymalizującego się przedsiębiorczego ja" mogą być wzmacniające, co już sygnalizowałam, lub regulujące. Warto podkreślić, że pewne zasoby, na przykład kapitał kulturowy lub tożsamościowy, mogą być nierówno rozdzielone. Poszczególne narracje dotyczące tożsamości nie są zatem $\mathrm{w}$ równym stopniu dostępne dla wszystkich. Nie możemy po prostu zdecydować o przyjęciu dowolnej tożsamości. Idąc dalej tym tokiem argumentacji, można stwierdzić, że niektóre kategorie uczących się mają większą swobodę, aby dokonać wyboru tego, jak usytuować się w ramach różnych narracji dotyczących tożsamości, upowszechnianych w dyskursach całożyciowego uczenia się, bądź swobodę tego, by z powodzeniem się im oprzeć. Kluczowe jest to, że tożsamości te są osadzone politycznie i historycznie. Dyskursy całożyciowego uczenia się określają uczącego się w sposób służący rekonstrukcji jego tożsamości ${ }^{11}$.

Perspektywą oglądu poruszanych tu zagadnień jest umiejscowienie całożyciowego uczenia się w innej globalnej tendencji, jaką jest, jak podkreśla Griffn, ucieczka od publicznego zabezpieczania potrzeb ku liberalnej gospodarce rynkowej. Podstawą tego procesu jest odpowiedzialność jednostki, a także reforma opieki społecznej i innych służb. Towarzyszy temu rozwój prywatnego sektora w świadczeniu usług oraz w obliczu globalizacji i gospodarki rynkowej wycofanie się rządu do roli strategicznej ${ }^{12}$.

Według Elliota, spory dotyczące tego, czy uczenie się jest zjawiskiem indywidualnym czy społecznym można zazwyczaj postawić obok sporów na temat progresywnego - w socjalno-demokratycznym znaczeniu tego słowa lub też nie, charakteru polityki całożyciowego uczenia się. Spór, według tego autora, $\mathrm{w}$ rzeczywistości dotyczy $\mathrm{w}$ takim samym stopniu odpowiedzialności jednostkowej czy społecznej za uczenie się, jak i natury uczenia się jako procesu. Autor ten stwierdza, że strategiczna rola rządu polega na "sterowaniu” poprzez selektywną interwencję, za pomocą takich środków, jak określanie celów, opracowywanie rankingów i wskazywanie wyników, a nie przez na-

${ }^{11}$ B. Morgan-Klein, M. Osborne, The Concepts and Practices, s. 20-21.

${ }^{12}$ C. Griffin, From education policy to lifelong learning strategies, [w:] The age of learning. Education and the knowledge society, red. P. Jarvis, London 2001. 
kazywanie i sankcjonowanie celów polityki ${ }^{13}$. Dyskurs dotyczy postrzegania całożyciowego uczenia się jako formy polityki edukacyjnej w warunkach neoliberalnej reformy opieki społecznej. Powszechny jest pogląd, że polityka całożyciowego uczenia się jest bardzo blisko związana z rządem socjaldemokratycznym, co z kolei łączy się z postrzeganiem procesu uczenia się jako z założenia fundamentalnie demokratycznego. Griffin sugeruje, przyjmując radykalny pogląd Elliotta, że w rzeczywistości całożyciowe uczenie się może być anty - edukacyjne [w znaczeniu anty-systemowe - E.S-A], gdyż odciąga fundusze i środki od publicznego systemu oświaty, w związku z czym, co chciałabym mocno podkreślić, można sobie wyobrazić politykę uczenia się przez całe życie jako pierwszy krok w kierunku destabilizacji i dezorganizacji systemu edukacji ${ }^{14}$.

Pogłębiając namysł nad tak radykalnie zarysowaną tezą, aktualnie chciałabym odnieść się do często podejmowanego w literaturze dotyczącej omawianej problematyki, zarówno tej o nachyleniu teoretycznym, jak i odnoszącej się bardziej do obszaru praktyki edukacyjnej, czy też raportującej szeroko rozumiane kwestie polityczne, problemu, jakim jest dysfunkcjonalność tradycyjnych instytucji edukacyjnych. Badacze zagadnienia zwracają uwagę na potrzebę "cichej rewolucji”, na konieczność nowego ładu edukacyjnego wykreowaną całożyciowym uczeniem się ${ }^{15}$. Jak podkreślają Ucher, Bryant, Johnson, ponowoczesność wymaga zmian dotychczasowych koncepcji edukacji i aktywności dorosłych, gdyż procesy edukacyjne stają się coraz bardziej zindywidualizowane, rozpatrywane jako rynkowe relacje pomiędzy producentem i konsumentem - mamy do czynienia z sytuacjami, gdzie upowszechnienie wiedzy odbywa się poza systemem instytucjonalnym ${ }^{16}$. W obszarze zmian paradygmatycznych określa się konieczność nowego ładu edukacyjnego związanego z całożyciowym uczeniem się, przejściem od nauczania do uczenia się dorosłych. Zajmowane przez badaczy stanowiska w tym względzie sytuują się od zrozumienia i akceptacji zmian wpisanych w nurt przeobrażeń współczesnego świata, po radykalizm wyrażający się wieszczeniem zmierzchu instytucjonalnej edukacji dorosłych, spowodowanego systematycznie poszerzającym się dostępem do wyższego wykształcenia, kryzysem państwa opiekuńczego, rosnącą sferą usług rodzącą zapotrzebowanie na odmienny charakter kwalifikacji, radykalną i krytyczną orientacją w naukach

${ }^{13}$ G. Elliott, Lifelong Learning: The politics of the new learning environment, London 1999, za: C. Griffin, tamże, s. 46.

14 Tamże, s. 44-47.

15 P. Alheit, Całożyciowe uczenie się i kapitał społeczny, Teraźniejszość - Człowiek - Edukacja, 2009, 4(48); M. Malewski, Od nauczania do uczenia się. O paradygmatycznej zmianie w andragogice, Wrocław 2010; M. Featherstone, Consumer Culture and Postmodernism, London 1991.

16 R. Usher, I. Bryant, R. Johnston, Adult Education and Postmodern Challenge. Learning Beyond the Limits, London - New York 1997. 
społecznych, czy „nadwątleniem kolektywistycznego i socjocentrycznego paradygmatu społeczeństwa jako systemu ${ }^{17}$. M. Malewski wskazuje, że utrata wiary w systemowy charakter świata i procesy postępującej biografizacji życia społecznego wywołały zjawisko „prywatyzacji” edukacji dorosłych, a jej wyzwolenie ze sztywnych ram programowych spowodowało to, że przyjęła ona postać naturalnego uczenia się. Autor ten koncepcję lifelong learning łączy nie tyle z przyrostem nowej wiedzy czy kompetencji, ile ze sposobem życia w społeczeństwie „opatrzonym warunkiem krytycznej samorefleksji i imperatywem zmienności"18.

Autor ten pisze także, iż

\begin{abstract}
wpisanie uczenia się w reżim programowy nauczania było aktem pacyfikacji formalnie deklarowanej autonomii i podmiotowości uczących się dorosłych. Deklaracje tego typu miały zamaskować i przesłonić redukcję człowieka dorosłego do roli ucznia, zamknąć go w sztucznym, intencjonalnie stworzonym środowisku edukacyjnym, podporządkować władzy pedagogicznego autorytetu szkoły i nauczyciela, skanalizować rozwój w obrębie z góry ustanowionych standardów kwalifikacyjnych, legitymizowanych ideologią ogólnospołecznego dobra i indywidualnego życiowego sukcesu ${ }^{19}$.
\end{abstract}

Odzwierciedlone w literaturze przedmiotu, a wyraźnie rysujące się w przestrzeni edukacyjnej problemy są złożone i zróżnicowane, zaś ich rozwiązanie w sferze polityki edukacyjnej i społecznej jest szczególnym wyzwaniem. Implikacje tych problemów dla instytucji funkcjonujących w ramach systemu edukacyjnego, co łączy się z kształceniem formalnym, są znaczące i powodują konieczność pogłębionych debat z zakresu polityki edukacyjnej. Implikacje te to między innymi: powtórna ewaluacja programów nauczania i procesów uczenia się oraz ich potencjalnie większa płynność; nacisk na indywidualnych uczących się i troska o zindywidualizowane drogi edukacyjne w perspektywie dostępności i równości szans; lepsza komunikacja pomiędzy instytucjami edukacyjnymi a zróżnicowanymi formami kształcenia nieformalnego oraz społecznościami.

W debatach dotyczących odchodzenia od konwencjonalnie ujmowanego szkolnictwa proponowane są dwa modele. Pierwszy przewiduje odejście od centralnej roli szkół jako instytucji, który to proces umożliwia rozwój nowoczesnych technologii i specyfika podłączonego do sieci społeczeństwa. Różnorodne sieci umożliwiające uczenie się na odległość zastąpiłyby tradycyjnie rozumiane instytucje edukacyjne. Także w tym kontekście podnoszony jest problem równości szans czy problem wykluczenia niektórych grup społecznych, który w tym modelu mógłby być trudny do rozwiązania. Trudny do re-

\footnotetext{
17 M. Malewski, Od nauczania do uczenia się, s. 84-91.

18 Tamże, s. 198.

19 Tamże, s. 175, 176.
} 
alizacji byłby także cel, jaki wiąże się z zakładanymi funkcjami szkół, którym jest dynamizowanie społeczności lokalnych ${ }^{20}$.

Zjawiskiem powszechnie akceptowanym jest to, że programy i wzory funkcjonowania edukacji wypracowane $w$ nowoczesności nie są adekwatne do ponowoczesnego świata, do wyzwań współczesności ${ }^{21}$. Analizy podstawowych dokumentów politycznych wyraźnie to obrazują - są bowiem wyrazem tendencji zmian $w$ omawianym obszarze i odpowiedzi na nowe potrzeby społeczno-kulturowe i ekonomiczne. Rozważając permanentny wzrost idei uczenia się przez całe życie, który ujmować można jako niezwykły przykład konsensusu politycznego na tak globalną skalę oraz w zakresie innowacyjnego narzędzia zarządzania polityką życia ${ }^{22}$, warto zwrócić uwagę na odzwierciedlenie przeobrażeń określonej idei edukacyjnej w polityce Unii Europejskiej, czy publikacjach i pracach UNESCO i OECD ${ }^{23}$, które odgrywają czołową rolę w wyznaczaniu trendów zmian i wnoszą główny wkład w określenie wizji całożyciowego uczenia się zarówno jako obszaru badań, jak i praktyki społecznej. Radykalizm stanowisk mówiących o zmierzchu instytucji edukacji dorosłych nie ma w nich odzwierciedlenia. Podkreślić jednak należy, że radykalizm ten wyrasta na gruncie głębokiej refleksji dotyczącej zasadniczych zmian paradygmatycznych, jakich doświadcza edukacja dorosłych, wyrasta też na gruncie przemyśleń nad naturą i kształtem tej edukacji w kontekście przeobrażeń społeczno-kulturowych. Stanowisko wiążące się z potrzebą analizy omawianego fenomenu edukacyjnego w tle szerszych procesów, ze szczególnym odniesieniem się do jego tła społeczno-kulturowego, uważam za podstawę poszukiwania odpowiedzi na wszelkie pytania, zarówno ogólne, jak i szczegółowe dotyczące problematyki nauczania i uczenia się dorosłych. W efekcie jego zastosowania określić można dwa wyraźnie zarysowujące się, współbieżne nurty dyskursu dotyczącego edukacji dorosłych postrzeganej w perspektywie całożyciowego uczenia się. Pierwszy z nich to refleksja nad zmniejszaniem się wyraźnie wyartykułowanej w latach 60. i 70. alokacyjnej funkcji edukacji dorosłych, rozumiana jako tak zwana "druga szansa", która traci na znaczeniu wobec sił rynkowych, wyborów indywidualnych i konsumeryzmu przejawiającego się w społecznych orientacjach wobec kształcenia. Nurt ten to równocześnie zwiększenie się roli indywidualnych wyborów edukacyjnych i uczenia się w pozainstytucjonalnych kontekstach, skutkujących wzrostem odpowiedzialności jednostek za przetrwanie

${ }^{20}$ B. Morgan-Klein, M. Osborne, The Concepts and Practices, s. 67.

${ }^{21}$ E. Solarczyk-Ambrozik, Ksztatcenie ustawiczne w perspektywie globalnej i lokalnej.

${ }^{22}$ P. Alheit, Podejście biograficzne do całożyciowego uczenia się, Teraźniejszość - Człowiek Edukacja, 2011, 3(55), s. 12.

${ }^{23}$ E. Solarczyk-Ambrozik, Uczenie się przez całe życie jako rzeczywistość edukacyjna; taże, Zmiany we wzorach przebiegu karier a całożyciowe uczenie się, [w:] Doradztwo zawodowe w perspektywie całożyciowego uczenia się, red. E. Solarczyk-Ambrozik, Poznań 2016. 
i utrzymanie się na rynku pracy, jako konsekwencji własnych decyzji i nakładów na edukację. Warto w tym miejscu przytoczyć także stanowisko mówiące o tym, że "antyinstytucjonalna”, jak nazywa ją P. Alheit, interpretacja uczenia się całożyciowego ignoruje fakt, że biograficzne uczenie się oraz instytucje edukacyjne są ze sobą powiązane ${ }^{24}$, a nowe, "zindywidualizowane" $i$ "spluralizowane" wzorce biegu życia są nadal kształtowane przez instytucje edukacyjne, które ze swej strony muszą dostosować się do nowych biografii powiązanych z całożyciowym uczeniem się $e^{25}$.

Drugim jest stale obecny i dynamicznie się rozwijający nurt "podaży” instytucjonalnej oferty kształcenia dorosłych, co ukazuje analiza polityki Unii Europejskiej, będącej również odpowiedzią na zmiany, w myśl założeń politycznych, legitymizująca treść i charakter przeobrażeń instytucjonalnych ${ }^{26}$. Żywotność i wartkość tego nurtu w edukacji dorosłych odzwierciedla choćby wyartykułowana $\mathrm{w}$ dokumentach politycznych i wdrażana $\mathrm{w}$ praktykę edukacyjną dążność do poprawy jakości kształcenia, dążenie do standaryzacji, czego egzemplifikacją może być ustanowienie Europejskich Ram Kształcenia.

W dyskurs całożyciowego uczenia się wpisany jest problem równych szans, czy inaczej artykułując - nierówności społecznych. W świecie, dla którego charakterystyczne są procesy indywidualizacji i refleksyjna modernizacja, struktura kompetencyjna może być rozwijana w ramach procesu całożyciowego uczenia się, co wymaga przebudowy całego systemu edukacyjnego ${ }^{27}$ i co wiąże się z tym, iż ryzyko wykluczenia społecznego jest większe niż w społeczeństwie industrialnym, przy czym, jak podkreśla P. Alheit,

logika wykluczenia społecznego nie nosi żadnych znamion nowości - kluczowymi determinantami pozostają klasa społeczna i płeć, ale równocześnie coraz większą rolę zaczynają odgrywać wiek i pochodzenie społeczne ${ }^{28}$.

Według tego autora, współczesne dyskursy kapitału społecznego i całożyciowego uczenia się sytuują się $\mathrm{w}$ głównym nurcie za cenę systematycznego wykluczania ludzi, których charakteryzuje ekonomiczne i edukacyjne ubóstwo. Idąc dalej w rozważaniach dotyczących całożyciowego uczenia się jako postmodernistycznej gry o władzę P. Alheit podkreśla, że „mglisty” charakter pojęcia całożyciowego uczenia się daje możliwości wykorzystania go jako instrumentu kontroli politycznej. Mówi, odnosząc się do koncepcji „rządomyślności" M. Foucault, o rządomyślności procesu całożyciowego ucze-

${ }^{24}$ P. Alheit, Podejście biograficzne do całożyciowego uczenia się, s. 14.

${ }^{25}$ Tamże, s. 10.

${ }^{26}$ E. Solarczyk-Ambrozik, Uczenie się przez całe życie jako rzeczywistość edukacyjna; taże, Zmiany we wzorach przebiegu karier.

${ }_{27}$ P. Alheit, Całożyciowe uczenie się i kapitat społeczny, s. 16.

${ }^{28}$ Tamże, s. 17. 
nia się wskazując na jego represyjny wymiar, co przy poddaniu dyskursu całożyciowego uczenia się prymatowi gospodarki skutkuje tym, że zmusza się jednostki do rozwijania "technik siebie”, równoznacznych z autoinstrumentalizacją ${ }^{29}$.

$\mathrm{W}$ podobny nurt ustosunkowań do polityki w zakresie całożyciowego uczenia się wpisują się badacze podejmujący analizowane zagadnienia z perspektywy feministycznej, zakładający, że współcześnie obszar całożyciowego uczenia się opiera się na pewnych ukrytych wartościach i założeniach. Ujawniają oni mechanizmy, poprzez które wybiórcze dyskursy i praktyki są kwestionowane i (re)konstruowane. Celem tego jest otwarcie nowych dróg konceptualizacji uczenia się, biorących pod uwagę wielorakie i zmieniające się w czasie formacje uczących się, jak również uczenie się w różnorodnych kontekstach społecznych. W ten sposób, w zamierzeniach, poszerzają zakres pojęcia uczenia się i rozumienia samego uczącego się, a także proponują inne, znacznie szersze, rozumienie całożyciowego uczenia się, uwzględniającego niedoceniane i błędnie rozpoznawane wartości, epistemologie i zasady ${ }^{30}$.

Jako społeczno-kulturowy kontekst całożyciowego uczenia się przyjmuje się zjawiska i procesy zachodzące w obrębie społeczeństwa uczącego się. Green argumentuje, że dyskurs społeczeństwa uczącego się przyjął charakter globalny z trzech powodów. Pierwszy jest związany ze starzeniem się populacji, co jest charakterystyczne dla wszystkich krajów rozwiniętych, drugi łączy się z kulturową zmianą, jaką jest przejście do i akceptacja "różnorodności stylów życia", trzeci zaś to globalna restrukturyzacja gospodarcza. Chociaż wydaje się, jak wskazuje ten autor, że przejawiana retoryka wartościuje wszystkie rodzaje uczenia się, dyskursy, w których rozważane są procesy zachodzące w obrębie społeczeństwa uczącego się obarczone są błędem uprzywilejowania pewnych rodzajów uczenia się oraz pewnych typów uczących się ${ }^{31}$.

Badacze sytuujący się we wspomnianym nurcie krytyki podkreślają, że istnieją szczególne sposoby postrzegania całożyciowego uczenia się, które zdobyły przewagę i to one mają głęboki wpływ na politykę i praktykę całożyciowego uczenia się, jednakże są one w zbyt małym stopniu kształtowane przez złożone, często sprzeczne i wieloaspektowe doświadczenia uczących się. Dzieje się tak głównie dzięki procesom i politykom związanym z walidacją wiedzy oraz sposobom, w jakich interpretują zmieniające się i skomplikowane nierówności społeczne ${ }^{32}$.

29 P. Alheit, Polityki dyskursu - całożyciowe uczenie sie jako postmodernistyczna gra o władzę? Teraźniejszość - Człowiek - Edukacja, 2010, 4(52).

30 P.J. Burke, S. Jackson, Reconceptualising Lifelong Learning. Feminist interventions, London 2007, s. 27.

31 A. Green, To Many Faces of Lifelong Learning: Recent Education Policy Trends in Europe, Journal of Education Policy, 2002, 17(6).

32 P. Burke, S. Jackson, Reconceptualising Lifelong Learning, s. 27. 
Pojawiają się argumentacje, że całożyciowe uczenie się konceptualizowane i prezentowane $\mathrm{w}$ różnych dyskursach i polityce jest bardziej czynnikiem kontroli społecznej niż czynnikiem zmian i działań transformacyjnych, stąd dyskurs na temat tego zjawiska utożsamia się z dyskursem na temat równości i szans edukacyjnych. W krytycznych podejściach, dokonywanych szczególnie z perspektywy feministycznej, podkreśla się, że całożyciowe uczenie się, mimo podkreślanego we wszystkich debatach politycznych jego znaczenia, produkuje i reprodukuje nierówności społeczne, gdyż preferuje określone formy i praktyki uczenia się oraz określone kategorie uczących się głównie dla potrzeb rozwojowych globalnej ekonomii, co pogłębia strukturalne nierówności.

Na przykład, akcentuje się, że dostęp do wyższych poziomów kształcenia czy pozaszkolnych form dających szanse ustawicznego doskonalenia zawodowego zróżnicowany jest klasowo, płcią, czy też innymi czynnikami o charakterze strukturalnym. Mimo retoryki rozszerzania udziału, która sugeruje bardziej inkluzyjny system szkolnictwa wyższego, masowość tego szkolnictwa spowodowała pojawienie się nowych nierówności zależnych od społecznej stratyfikacji. Argumentuje się, że kultura edukacyjna realizowana na poziomie szkolnictwa wyższego, jego dynamiczny rozwój, kontynuuje uprzywilejowanie maskulinistycznych epistemologii i legitymizuje założenia i wartości klasy średniej.

Całożyciowe uczenie się ujmuje się jako dyscyplinujący mechanizm, mający na celu kontrolę "globalnych" obywateli w sytuacji stałego zagrożenia ryzykiem, które dotyka zarówno społeczeństwo globalne, jak i społeczności lokalne.

Kształcenie staje się polem walki o wiedzę, co oznacza, że zdominowane władzą dyskursy określają kształt obowiązującej wiedzy, jedynej i prawdziwej, dostępnej w procesie uczenia się przez całe życie, wartościowej dla globalnej ekonomii i rynków pracy. Jak podkreślają Burke i Jackson, nadejście dwudziestego pierwszego wieku zostało na świecie odebrane jako moment, który wielu jednostkom, społeczeństwom i rządom przyniósł liczne wyzwania i zagrożenia, między innymi zmieniający się charakter pracy, przemiany technologiczne, globalizację, nieprzewidywalność środowiska, terroryzm i wojny, ogólną niepewność. Atrakcyjność metod naukowych w tych warunkach polega na tym, że postrzega się je jako przynoszące niezawodne, obiektywne i prawidłowe dane, które pomagają radzić sobie z zagrożeniami i niepewnością. Zakłada się, że „właściwa” wiedza sprawi, że będziemy mogli kontrolować nasze otoczenie i minimalizować ryzyko. Panuje przekonanie, że gromadzenie kapitału wiedzy i stworzenie "gospodarki wiedzy" ograniczy zagrożenia, dla określonych jednak kategorii jednostek i społeczności, zmagających się z coraz bardziej niestabilnym światem. W takim kontekście całożyciowe uczenie się postrzegane jest jako „kluczowa strategia" ${ }^{33}$.

${ }^{33}$ Tamże, s. 28. 
Istotna staje się kwestia, jak już wspomniałam wcześniej, oglądu fenomenu całożyciowego uczenia się w szerszym społeczno-kulturowym kontekście, co pozwala analizować określone praktyki, określone tożsamości uczących się, czy też nierówności w edukacji. Uwaga skupia się nie tylko na tym, w jaki sposób czynniki społeczno-ekonomiczne mogą utrudniać uczestnictwo, ale również na tym, jak sytuacje i instytucje edukacyjne mogą powielać relacje siłowe, czy to poprzez treść programów nauczania, czy też poprzez stosowane praktyki pedagogiczne, które mogą służyć aktywnemu wykluczaniu niektórych grup ${ }^{34}$. Warto przypomnieć, że w hegemonicznym dyskursie całożyciowego uczenia się szczególnie eksponowane są wartości indywidualnej przedsiębiorczości, podejmowania ryzyka, czy konkurencyjności, co ma znaczące implikacje dla aktywności edukacyjnej określonych jednostek, dla innych stanowić może czynnik edukacyjnej ekskluzji.

Niektórzy badacze krytykują jednak podejście koncentrujące się na problemach ekskluzji, jako odciągające uwagę od zasadniczych kwestii nierówności społecznych i niesprawiedliwości, czego efektem jest to, iż specyficzne wartości kulturowe i określone perspektywy - drogi przebiegu karier życiowych charakterystyczne dla klasy średniej, legitymizowane są bez uwzględniania ich implikacji w perspektywie społecznej sprawiedliwości. Jak wskazują Burke i Jackson, dyskurs podnoszenia i dynamizowania aspiracji nie uwzględnia, czy przynajmniej marginalizuje kwestie wzajemnych relacji, jakie zachodzą pomiędzy aspiracjami jednostki a ich klasowym i genderowym uwarunkowaniem a identyfikacją, a także pomiędzy społecznym doświadczeniem jednostek. Ignoruje również instytucjonalny i kulturowy kontekst, w którym kształtuje się podmiotowość35. Archer i Leathwood wskazują ponadto, że nie uwzględnia się faktu, że osoby klasyfikowane jako nie uczestniczące w systemie kształcenia mogą nie chcieć podejmować takiej aktywności, preferując uczenie się w przestrzeni pozainstytucjonalnej ${ }^{36}$.

Ujmowany w podejściach krytycznych jako dominujący sposób myślenia o uczącym się przez całe życie nie uwzględnia, w świetle tych krytycznych ustosunkowań, zróżnicowań jego sytuacji w kontekście narodowym, etnicznym, klasowym, czy genderowym i, co podkreśla się, kwestie dotyczące tożsamości osób uczących się i różnic często wyłączone są z politycznych debat na temat tego, kto i w jakich formach uczestnictwa powinien brać udział ${ }^{37}$.

Autorzy sytuujący się $\mathrm{w}$ feministycznym poststrukturalnym podejściu ukazują wiedzę na temat całożyciowego uczenia się - uprzywilejowaną

${ }^{34}$ B. Morgan-Klein, M. Osborne, The Concepts and Practices, s. 14

${ }_{35}$ P.J. Burke, S. Jackson, Reconceptualising Lifelong Learning, s. 17.

${ }^{36}$ L. Archer, M. Hutchings, A. Ross, Higher Education and Social Class: Isues of Exlusion and Inclusion, London 2003.

${ }^{37}$ P.J. Burke, S. Jackson, Reconceptualising Lifelong Learning. 
w akademickich i politycznych dyskursach, jako nie, jak jest w nich przedstawiana, neutralną, obiektywną, apolityczną, wolną od wartości, ale powiązaną z władzą określonym układem sił, genderową. Brak świadomości tego, że wiedza jest społecznie konstruowana i odczytywana w określonym kontekście zwiększa, zdaniem tych autorów, kulturowe, społeczne i materialne nierówności osadzone w politykach i praktykach całożyciowego uczenia się ${ }^{38}$.

Definicje całożyciowego uczenia się konstruowane są w sprzeczny sposób poprzez różne modele epistemologiczne dostępne badaczom. Pojęcie dyskursu jest szczególnie pomocne $\mathrm{w}$ rozumieniu i interpretowaniu procesu definiowania całożyciowego uczenia się konstruowanego przez politykę, praktykę i opisywanego przez badania. Dyskursy całożyciowego uczenia się instytucjonalizują i regulują zarówno „znormalizowane”, jak i krytyczne rozumienie tego czym jest uczenie się i kto jest uznawany za uczącego się. Burke i Jackson zwracają uwagę na to, że $\mathrm{w}$ tym samym czasie i przestrzeni istnieje wiele sprzecznych interpretacji procesu uczenia się przez całe życie ${ }^{39}$. Morgan-Klein i Osborne stwierdzają kategorycznie, że dyskursy całożyciowego uczenia się nie są neutralne. Są zróżnicowane, potencjalnie sprzeczne i permanentnie się zmieniają. Mają moc wywoływania znaczącej zmiany społecznej w wielu wymiarach, przy czym zmiana ta jest nieuchronnie kontrowersyjna ${ }^{40}$.

Co rozumiemy poprzez całożyciowe uczenie się, kogo uznajemy za osobę uczącą się, jakie są motywy aktywności edukacyjnej, czy z szerszej perspektywy patrząc - jakie wyzwania współczesnego świata kształtują potrzeby uczenia się przez całe życie, jakie problemy podejmujemy wyjaśniając fenomen całożyciowego uczenia się - odpowiedzi na te pytania różnicują epistemologiczne podejścia stosowane przez różnych badaczy, a także ustalenia badawcze uzyskane w efekcie tych zróżnicowanych podejść.

Analiza tych ustosunkowań do idei i praktyk edukacyjnych pozwala na stwierdzenie zróżnicowania ram koncepcyjnych, w obrębie których pojęcie całożyciowego uczenia się jest omawiane, co skutkuje odwołaniem się do nich w różnych debatach politycznych i zróżnicowanych politycznie strategiach oświatowych. Można jednak stwierdzić, w efekcie analizy literatury sygnalizowanej wyżej, że istnieją pewne szczególne podejścia do fenomenu całożyciowego uczenia się, które dominują i to one mają wpływ na politykę i praktykę $\mathrm{w}$ tym zakresie.

Nicoll i Edwards ${ }^{41}$ analizując stosowne polityki, ukazują całożyciowe uczenie jako szczególny zamysł retoryczny mający na celu mobilizowanie

38 Tamże, s. 17.

39 Tamże.

40 B. Morgan-Klein, M. Osborne, The Concepts and Practices, s. 67.

41 K. Nicoll, R. Edwards, Lifelong Learning and the Sultans of Spin: Policy as Persuasion? Journal of Education Policy, 2004, 19(1), s. 43-55. 
jednostek i grup społecznych do uczestniczenia w zmianie. Warto zwrócić uwagę na charakter programów uczenia się przez całe życie, ujętych w różnego rodzaju dokumentach strategicznych Unii Europejskiej, raportach, materiałach konferencyjnych, publikacjach o charakterze teoretycznym, które ukazują uczenie się przez całe życie zarówno jako ideę edukacyjną, określoną politykę, jak i strategie działań ${ }^{42}$. Łączą uczenie się przez całe życie z potrzebami rynku pracy, co oznacza $w$ podstawowych założeniach zwiększenie dzięki tej aktywności edukacyjnej szans jednostek na zatrudnienie, zapewnienie pomyślnej kariery zawodowej oraz łatwość przemieszczania się między sektorami a także państwami, przechodzenie z pracy do nauki i z nauki do pracy w ciągu całego życia. W strategiach uczenia się, jako wykładniach założeń politycznych formułowanych na poziomie Unii Europejskiej, rysuje się silny trend na integrację z elementami polityk dotyczących takich kwestii, jak zatrudnienie i integracja społeczna. Widać silne sprzężenie polityki w zakresie uczenia się przez całe życie z polityką unijną w sferze socjalnej, dotyczącą jakości życia, pryncypiów leżących u podstaw wspólnoty europejskiej. Duży nacisk położony jest na strategie zwiększania dostępu do uczenia się poprzez całe życie, zwłaszcza grupom defaworyzowanym, walkę z ubóstwem. Wspomniane dokumenty obrazują krystalizowanie się koncepcji uczenia się przez całe życie i możliwości wpisania jej w rzeczywistość edukacyjną ${ }^{43}$.

Jak widać z przedstawionych tutaj analiz, mimo normatywnego podejścia, szczególnie widocznego $\mathrm{w}$ strategiach formułowanych na różnym poziomie (europejskim, regionalnym, lokalnym), sam fenomen uczenia się przez całe życie nie poddaje się jednoznacznej ocenie. Całożyciowe uczenie się może być pojmowane jako cel edukacji, proces, produkt edukacji, forma samorealizacji czy też przymus społeczno-kulturowy, cywilizacyjny, obszar rzeczywistości edukacyjnej, czy używając określenia Edwardsa „kłopotliwa przestrzeń konceptualna". Jawi się zatem pytanie: w jakim stopniu i w jaki sposób idea całożyciowego uczenia się strukturyzuje nasze myślenie o rzeczywistości społecznej, a także w jaki sposób rzeczywistość społeczna, kulturowa, czy ekonomiczna wyznacza potrzebę uczenia się przez całe życie, określając je jako szansę sprawnego poruszania się w zmiennym świecie (nie)równych szans.

\section{BIBLIOGRAFIA}

Alheit P., Całożyciowe uczenie się i kapitał społeczny, Teraźniejszość - Człowiek - Edukacja, 2009, 4(48).

Alheit P., Polityki dyskursu - całożyciowe uczenie się jako postmodernistyczna gra o władzę? Teraźniejszość - Człowiek - Edukacja, 2010, 4(52).

${ }^{42}$ E. Solarczyk-Ambrozik, Uczenie się przez całe życie jako rzeczyzistość edukacyjna.

${ }^{43}$ Tamże. 
Alheit P., Podejście biograficzne do całożyciowego uczenia się, Teraźniejszość - Człowiek - Edukacja, 2011, 3(55).

Archer L., Hutchings M., Ross A., Higher Education and Social Class :Issues of Exclusion and Inclusion, Routledge, London 2003.

Archer L., Leathwood C., Identities, Inequalities and Higher Education, [w:] Higher Education and Social Class: Issues of Exclusion and Inclusion, red. L. Archer, M. Hutchings, A. Ross, Routledge, London 2003.

Bloomer M., Hodkinson P., Learning careers: Continuity and change in young people's dispositions to learning, British Educational Research Journal, 2000, 26(5).

Burke P.J., Jackson S., Reconceptualising Lifelong Learning. Feminist interventions, Routledge, London 2007.

Crowther J., "In and Against" lifelong learning: Flexibility and the corrosion of character, International Journal of Lifelong Education, 2004, 23(2).

Elliott G., Lifelong Learning: The politics of the new learning environment, Routledge \& Kegan Paul, London 1999.

Featherstone M., Consumer Culture and Postmodernism, Sage Publications, London 1991.

Green A., The Many Faces of Lifelong Learning: Recent Education Policy Trends in Europe, Journal of Education Policy, 2002, 17(6).

Griffin C., From education policy to lifelong learning strategies, [w:] The age of learning. Education and the knowledge society, red. P. Jarvis, Kogan Page, London 2001.

Malewski M., Od nauczania do uczenia się. O paradygmatycznej zmianie w andragogice, Wydawnictwo Naukowe Dolnośląskiej Szkoły Wyższej, Wrocław 2010.

Morgan-Klien B., Osborne M., The Concepts and Practices of Lifelong Learning, Routledge, London - New York 2007.

Nicoll K., Edwards R., Lifelong Learning and the Sultans of Spin: Policy as Persuasion? Journal of Education Policy, 2004, 19(1).

Skeggs B., Class, Self, Culture, Routledge, London 2004.

Solarczyk-Ambrozik E., Makrostrukturalne uwarunkowania zmienności systemu oświaty dorostych, [w:] Zmiana spoteczna a kompetencje edukacyjne dorostych, red. K. Przyszczypkowski, E. Solarczyk-Ambrozik, Wydawnictwo Miscellanea, Koszalin 1995.

Solarczyk-Ambrozik E., Ksztatcenie ustawiczne w perspektywie globalnej i lokalnej. Między wymogami rynku a indywidualnymi strategiami edukacyjnymi, Wydawnictwo Naukowe UAM, Poznań 2009.

Solarczyk-Ambrozik E., Uczenie się przez całe życie jako rzeczywistość edukacyjna. Dyskurs catożyciowego uczenia się w tle zmian społeczno-ekonomicznych, [w:] Całożyciowe uczenie się jako wyzwanie dla teorii i praktyki edukacyjnej, red. E. Solarczyk-Ambrozik, Wydawnictwo Naukowe UAM, Poznań 2013.

Solarczyk-Ambrozik E., Zmiany we wzorach przebiegu karier a całożyciowe uczenie się, [w:] Doradztwo zawodowe w perspektywie catożyciowego uczenia się, red. E. Solarczyk-Ambrozik, Wydawnictwo Naukowe UAM, Poznań 2016.

Usher R., Bryant I., Johnston R., Adult Education and Postmodern Challenge. Learning Beyond the Limits, Routledge, London - New York 1997.

Usher R., Edwards R., Lifelong Learning - Signs, Discourses, Practices, Springer, Dordrecht 2007. 